Helper, Vol 35 No 1 (2018) - 11

\title{
PENGARUH TEKNIK DISKUSI DALAM BIMBINGAN KELOMPOK TERHADAP KEMAMPUAN KOMUNIKASI INTERPERSONAL SISWA KELAS VII H SMP NEGERI 21 SURABAYA
}

Oleh:

\author{
Aulia Putri Fadmazati \\ (Bimbingan dan Konseling, Fakultas Keguruan dan Ilmu Pendidikan, Universitas \\ PGRI Adi Buana Surabaya ) \\ Zetibk14@gmail.com
}

Maghfirotul Lathifah, S.Pd., M.Pd.

(Dosen Bimbingan dan Konseling, Fakultas Keguruan dan Ilmu Pendidikan, Universitas PGRI Adi Buana Surabaya )

Maghfirotul@unipasby.ac.id

\begin{abstract}
Abstrak
Komunikasi interpersonal adalah proses penyampaian informasi baik dilakukan oleh dua orang atau lebih secara langsung atau tidak langsung dengan adanya umpan baliak. Proses komunikasi tidak selamanya dapat berjalan lancar, ditemukan di kelas VII H SMP Negeri 21 Surabaya sering terjadi kesalahpahaman karena kurangnya kemampuan komunikasi interpersonal untuk meningkatkan kemampuan komunikasi interpersonal digunakan teknik diskusi dalam bimbingan kelompok. Tujuan dari penelitian ini adalah untuk mengetahui pengaruh penggunaan teknik diskusi dalam bimbingan kelompok terhadap komunikasi interpersonal siswa metode yang digunakan dalam penelitian ialah pre-experiment sesuai dengan tujuan penelitian, maka sampel yang digunakan ialah porposive sampel dengan jumlah 6 siswa kelas VII H. Instrumen pengumpulan yang digunakan dengan skala komunikasi interpersonal, sedangkan teknik analisis data yang digunakan parametrik dan uji hipotesis menggunakan t-test. Hasil penelitian menunjukan adanya pengaruh teknik diskusi dalam bimbingan kelompok terhadap kemampuan komunikasi interpersonal siswa, hal ini ditunjukan dengan rerata komunikasi interpersonal siswa sebesar 150,67 kategori tersebut merupakan kategori tinggi. Artinya ada perbedaan antara hasil pre test dan post test. Hal itu dapat dilihat dari sikap siswa yang mulai berani bertanya dan mengemukakan pendapat, bersikap tenang dan tertib selama proses pemberian layanan, mau mendengarkan temannya yang sedang menyampaikan pendapat di depan kelas, mengerti pesan yang disampaikan guru, dan segera menjawab pertanyaan serta mengikuti perintah yang diberikan guru.
\end{abstract}

Kata kunci: Teknik Diskusi, Komunikasi Interpersonal 


\section{PENDAHULUAN}

Seorang siswa berinteraksi dan bergaul dengan teman sebaya maupun guru di sekolah perlu melakukan komunikasi interpersonal, hal ini karena komunikasi interpersonal adalah sarana dalam menjalin interaksi di lingkungan sekolah. Devito (2011) mengungkapkan komunikasi merupakan satu proses pengiriman dan penerimaan pesanpesan antara dua orang atau diantara sekelompok kecil orang-orang dengan beberapa efek dan beberapa umpan balik seketika. Komunikasi interpersonal memiliki lima aspek yaitu keterbukaan (Openess), empati (Empathy), sikap mendukung (Supportiveness), sikap positif (Positiveness), kesetaraan (Equality).

Proses komunikasi tidak selamanya dapat berjalan lancar. Setiap individu memiliki kemampuan bersosialisasi yang berbeda, kemampuan berkomunikasi setiap individu dapat di pengaruhi oleh latar belakang kehidupan yang berbeda, baik dari segi pendidikan orang tua, pendidikan formal, gaya hidup, ekonomi, lingkungan tempat tinggal maupun kesehatan, sehingga perbedaan tersebut sering menghambat proses komunikasi antar individu.

Berdasarkan hasil observasi di kelas VII H SMP Negeri 21 Surabaya diketakui bahwa siswa siswi mengalami tingkat komunikasi yang rendah, dapat dilihat dari sering terjadi kesalahpahaman yang mengakibatkan perselisihan antar siswa. Kesalahpahaman ini dapat dijumpai disaat jam pelajaran ataupun di luar jam pelajaran. Banyak siswa terpancing dengan ulah temannya yang mengeluarkan kalimat untuk mengundang kelucuan sebagai penghangat pembicaraan. Hal ini tidak jarang membuat salah satu dari mereka merasa tersinggung dan mengakibatkan pertengkaran, perkelahian, ataupun saling mencela satu sama lain dengan mengucapkan kata-kata kotor yang tidak pantas diucapkan oleh siswa.

Hasil penelitian pendahulu yang dilakukan oleh Astuti dalam Rahmayanti (2014) menjelaskan 62\% dari 50 siswa sekolah menengah pertama memiliki permasalahan yang berhubungan dengan komunikasi yang terbukti siswa gugup apabila bicara 
dengan orang yang belum dikenal, merasa gemetar apabila berhadapan dengan orang banyak, tidak berani mengemukakan pendapat di depan umum, dan takut mendapat kritikan.

Melihat fenomena tersebut, sudah seharusnya semua pendidik mulai melakukan perhatian khusus. Apabila fenomena tersebut tidak segera diatasi maka menimbulkan dampak yang cukup besar bagi kehidupan siswa. Siswa yang mengalami kegagalan dalam melakukan komunikasi interpersonal dengan lingkungannya, mengakibatkan siswa tidak diterima, ditolak dan dikucilkan. Kegagalan melakukan komunikasi interpersonal membuat siswa semakin mengalami kesulitan dalam melakukan interaksi sosial yang lebih luas.

Dampak dari kemampuan berkomunikasi interpersonal yang kurang baik cenderung menghambat pembentukan kepribadian dalam kehidupan, terutama dalam meraih prestasi di sekolah dan dikhawatirkan dapat menimbulkan persoalan lain yang lebih kompleks.

Berbagai bentuk komunikasi interpersonal dapat dipengaruhi oleh berbagai faktor, Menurut Suranto (2011) ada beberapa faktor yang sangat menentukan keberhasilan komunikasi interpersonal apabila dipandang dari sudut komunikator, komunikan dan pesan yang disampaikan.

Diskusi kelompok menurit Sukardi (2008) "suatu pertemuan dua orang atau lebih, yang ditunjukkan untuk saling tukar pengalaman dan pendapat, dan biasanya menghasilkan suatu keputusan bersama". Diskusi pada hakikatnya adalah kerjasama dalam mengumpulkan dan tukar-menukar pengalaman serta gagasan. Melalui diskusi, siswa dibina memperhatikan kepentingan orang lain, menghargai pendapat orang lain, dan menerima keputusan bersama. Melalui diskusi kelompok ini, peneliti dapat mendorong siswa untuk melatih kemampuan berpendapat, menyatakan gagasan, perasaan, serta meningkatkan kepercayaan dirinya sehingga siswa nantinya dapat berkomunikasi interpersonal secara lebih baik lagi di lingkungan sosial yang lebih luas.

Berdasarkan uraian di atas dapat disimpulkan bahwa dengan menggunakan teknik diskusi maka 
seorang individu mampu memecahkan masalah yang dialaminya dengan cara berdiskusi agar dia dapat menyatakan atau menegaskan diri serta mampu untuk mengekspresikan perasaannya secara bebas, sehingga dengan melakukan hal tersebut maka kemampuan siswa dalam berkomunikasi interpersonal juga akan meningkat.

Penelitian ini bertujuan untuk mengetahui pengaruh penggunaan teknik diskusi dalam bimbingan kelompok terhadap komunikasi interpersonal siswa.

\section{METODE PENELITIAN}

Penelitian ini menggunakan penelitian pre-experiment dengan menggunakan pendekatan kuantitatif. Desain penelitian yang digunakan adalah One Group Pretest-Posttest Design karena dalam rencana ini digunakan satu kelompok subjek. Penelitian ini dilaksanakan di SMP Negeri 21 Surabaya.

Populasi penelitiana adalah kelas VII $\mathrm{H}$ yang menjadi target penelitian, yaitu sebanyak 34 siswa-siswi, pemilihan sampel dalam penelitian ini dengan nonprobability sampling menggunakan teknik sampling porposive adalah teknik penentuan sampel dengan pertimbangan tertentu. Sampel yang diambil berjumlah 6 siswa yang memiliki kemampuan komunikasi interpersonal rendah.

Metode pengumpulan data yang digunakan dalam penelitian ini adalah skala psikologis dan alat pengumpul data yang digunakan berupa skala komunikasi interpersonal. Pengujian dalam penelitian ini adalah dengan menggunakan teknik analisis parametrik. Teknik analisis data parametrik digunakan karena memenuhi asumsi normalitas. Hasil kolmogorovsmirnov diperoleh 0.162 dengan sig 0.200 yang berarti sig $>0.050$

\section{HASIL PENELITIAN}

Penggunaan teknik diskusi dalam bimbingan kelompok berpengaruh terhadap kemampuan komunikasi interpersonal siswa ". Hal ini ditunjukan dengan hasil t-test 0,001. Artinya "Ha diterima". Ada perbedaan yang siknifikan antara hasil pre test dan post test, sehingga dapat disimpulkan pula bahwa. 


\section{PEMBAHASAN}

Kemampuan siswa dalam berkomunikasi dengan orang lain untuk dapat mengembangkan keterampilan komunikasi interpersonal yang dimilikinya, karena kemampuan berkomunikasi merupakan suatu kemampuan yang paling dasar yang harus dimiliki seseorang. komunikasi merupakan satu proses sosial dimana orang-orang yang terlibat saling mempengaruhi. Devito (1998) dalam Sugiyo (2005) mengatakan bahwa Komunikasi interpersonal memiliki 5 ciri yaitu: keterbukaan (Openess), empati (Empathy), sikap mendukung (Supportiveness), sikap positif (Positiveness), kesetaraan (Equality) .

Diskusi pada hakikatnya adalah kerjasama dalam mengumpulkan dan tukar-menukar pengalaman serta gagasan. Melalui diskusi, siswa dibina memperhatikan kepentingan orang lain, menghargai pendapat orang lain, dan menerima keputusan bersama. Melalui diskusi kelompok ini, peneliti dapat mendorong siswa untuk melatih kemampuan berpendapat, menyatakan gagasan, perasaan, serta meningkatkan kepercayaan dirinya sehingga siswa nantinya dapat berkomunikasi interpersonal secara lebih baik lagi di lingkungan sosial yang lebih luas.

Teknik diskusi merupakan salah satu cara untuk dapat membantu siswa dalam memecahkan masalah keterampilan komunikasi interpersonal. Dalam pemberian layanan dan teknik diskusi peneliti memiliki kekurangan dalam memberikan pelayanan, dari segi waktu dan tempat sebagai berikut:

1. Pemberian teknik yang kurang maksimal dalam penerapan teknik diskusi, dalam hal mengajak siswa untuk mengikuti kegiatan secara tertib.

2. Peneliti sekaligus berperan menjadi konselor, sehingga kurang maksikmal dalam melaksanakan apa yang dikerjakan.

3. Peneliti tidak bisa melakukan penelitian selama satu bulan dikarenakan ada persiapan UAS sampai libur akhir tahun, sehinggah sisawa merasa asing saat pemberian treatmen kembali.

Berdasarkan hasil analisis data yang telah dilakukan dengan menggunakan 
skala pengukuran kemampuan komunikasi interpersonal siswa dengan perhitungan t-test diperoleh hasil rata-rata sebesar 119.50 hal ini lebih rendah jika dibandingkan dengan setelah dilakukan treatmen, hasil yang diperoleh yaitu 150.67 yang artinya ada peningkatan sebelum dilakukan treatmen dan setelah di lakukannya treatment. Hasil dari uji analisis di atas menunjukkan bahwa hipotesis yang telah ditulis pada bab sebelumnya diterima, yang artinya ada perbedaan peningkatan kemampuan komunikasi interpersonal antara sebelum dan sesudah diberi treatment. Dengan demikian dapat dikatakan bahwa teknik diskusi efektif untuk meningkatkan kemampuan komunikasi interpersonal pada siswa kelas VII H SMP Negeri 21 Surabaya.

\section{SIMPULAN}

Berdasarkan hasil penelitian yang telah dilakukan dan pembahasan penelitian mengenai upaya meningkatkan komunikasi interpersonal siswa melalui bimbingan kelompok dengan menggunakan teknik diskusi, maka dapat disimpulkan bahwa komunikasi interpersonal siswa kelas VII H di SMP Negeri 21 Surabaya sebelum diberikan bimbingan kelompok dengan teknik diskusi menunjukkan kategori rendah dan sedang, setelah diberikan bimbingan kelompok dengan teknik diskusi menunjukkan kategori tinggi, peningkatan tingkat komunikasi interpersonal dapat dilihat dari nilai skor rata-rata komunikasi interpersonal, hal tersebut dilihat dari tahap Pretest hingga Posttest. Hasil tersebut diantaranya:

1. Rata-rata skor pada Pretest 119.50

2. Rata-rata skor Posttest 150.67

Ada perbedaan yang siknifikan antara hasil pre test dan post test, sehingga dapat disimpulkan pula bahwa "penggunaan teknik diskusi dalam bimbingan kelompok berpengaruh terhadap kemampuan komunikasi interpersonal siswa".

\section{SARAN}

Berdasarkan kesimpulan hasil penelitian yang telah dikemukakan diatas, maka dapat diajukan beberapa saran sebagai berikut:

1. Bagi siswa kelas VII H SMP Negeri 21 Surabaya 
Siswa diharapkan mampu atau lebih berani mengungkapkan pendapat dan lebih aktif dalam diskusi kelompok agar komunikasi interpersonal siswa dapat meningkat.

2. Bagi guru BK SMP 21 Surabaya guru BK agar lebih mengoptimalkan layanan bimbingan kelompok dengan menggunakan teknik diskusi sebagai strategi alternatif untuk meningkatkan komunikasi interpersonal siswa.

3. Bagi peneliti selanjutnya

Bagi peneliti lain yang tertarik untuk memperkuat penelitian ini, dapat melakukan penelitian dalam jenjang pendidikan yang berbeda selain SMP, jenis layanan yang berbeda selain bimbingan kelompok, dan teknik yang berdeda selain dengan teknik diskusi sehingga akan diperoleh wawasan tambahan.

\section{DAFTAR PUSTAKA}

Devito, Joseph. 2011. Komunikasi Antarmanusia. Tanggerang Selatan: Karisma Publishing Group

Rahmayanti, Farrah. 2014. Program peningkatan keterampilan komunikasi interpersonal melalui permainan

kelompok.http://repository.upi.edu/1 3116/4/S_PPB_0901499_Chapter1.p df, diakses pada 21 juli 2017 pukul 11:29 WIB.

Sugiyo. 2005. Komunikasi Antar Pribadi. Semarang: UNNES PRESS.

Sukardi, Dewa Ketut. 2008. Proses Bimbingan dan Konseling di Sekolah. Jakarta: Rineka Cipta.

Suranto. 2011. Komunikasi Interpersonal. Yogyakarta: Graha Ilmu. 
Helper, Vol 35 No 1 (2018) - 18

"HELPER" Jurnal Bimbingan dan Konseling FKIP UNIPA 